\title{
Peningkatan Kemampuan Berpikir Kritis Siswa SMA dengan Model Inkuiri pada Materi Sistem Indera
}

\author{
Increasing the High School Students' Critical Thinking through Inquiry \\ Learning
}

\author{
Wahyu Setiya Roning Perdani ${ }^{1}$, Slamet Santosa ${ }^{1}$, Murni Ramli ${ }^{1}$ \\ ${ }^{1}$ Pendidikan Biologi FKIP UNS, Surakarta, Indonesia. \\ *Corresponding authors: wahyusetiya99@gmail.com
}

Manuscript received: ......... Revision accepted:

\begin{abstract}
The aim of this research is to increase the students' critical thinking through inquiry learning. This research was a classroom action research with 3 cycles conducted from March until April 2015. Each cycle consisted of 4 phases, i.e. planning, acting, observing, and reflecting. The participants of the research are 34 students of grade XI MIA 6 SMAN 4 Surakarta. Data was obtained from questionnaire, multiple choices test, and interview. The main data of the students' critical thinking includes several aspects as follows: interpretation, analysis, evaluation, inference, explanation, and self-regulation. Data was analyzed descriptively, and validated using a triangulation method. The research procedure used was the spiral method by Kemmis and Mc.Taggart. The result of the research shows that inquiry learning increased the students' critical thinking. The student's critical thinking from the pre cycle is $35,04 \%$, the first cycle is $42,40 \%$, the second cycle is $51,71 \%$, the third cycle is $63,97 \%$
\end{abstract}

Keywords: Inquiry Learning, Critical Thinking, System of Senses

\section{PENDAHULUAN}

Pendidikan mempunyai peranan yang penting dalam berbagai bidang kehidupan. Pendidikan pada abad ke-21 bukan hanya berorientasi pada mengenal konsep, melainkan harus mulai memberikan kesempatan siswa untuk berpikir sains. Pembelajaran sains adalah pembelajaran yang mengkondisikan siswa untuk aktif dalam proses pembelajaran, dapat memberikan pengalaman kepada siswa, dan mampu membentuk pemahaman siswa tentang materi pelajaran yang dipelajari. Kemampuan siswa untuk mengkonstruksi pola pikirnya sendiri menjadi tujuan dari pembelajaran sains yang disesuaikan dengan tuntutan perkembangan jaman. Menurut Trilling dan Hood (1999) serta Nursito (2000), perkembangan jaman pada abad 21 ini diperlukan sumber daya manusia dengan kualitas tinggi yang mempunyai beberapa kemampuan, antara lain kemampuan bekerja sama, memahami keberagaman budaya, menguasai IPTEKS, mampu belajar sepanjang hayat serta berpikir tingkat tinggi.

Menurut Liliasari (2011), berpikir tingkat tinggi di antaranya meliputi kemampuan berpikir kritis (tajam dalam menganalisis) dan kreatif (bersifat daya cipta). Kemampuan berpikir baik kemampuan berpikir kritis maupun berpikir kreatif merupakan hal penting dan sangat diperlukan peserta didik untuk menghadapi persoalan hidup di masa yang akan datang. Berpikir tingkat tinggi di bidang pendidikan nantinya akan membantu siswa dalam memecahkan suatu masalah yang dihadapi dalam proses belajar. Kemampuan berpikir kritis pada siswa menjadi hal yang sangat penting, karena pada umumnya masalah nyata di dunia saat ini tidak sederhana. Kemampuan berpikir kritis siswa adalah hal yang perlu dikembangkan agar kemampuan berpikir siswa dapat terlatih dalam proses pembelajaran (Redhana dan Liliasari,2008). Hasil observasi terhadap proses pembelajaran biologi kelas XI MIA 6 SMA N 4 Surakarta tahun ajaran 2014/2015 melalui pengamatan langsung pada hari Senin, 20 Oktober 2014 menunjukkan bahwa persentase siswa bertanya mengenai materi yang yang belum dipahami sebesar 13,33\%. Siswa memberikan penjelasan atas pertanyaan yang diberikan guru disertai pendapat yang logis atau referensi yang mendukung sebesar $11,11 \%$. Siswa memberikan penjelasan atas pertanyaan yang diberikan guru tanpa disertai pendapat yang logis atau referensi yang mendukung sebesar 33,33\%. Pada kegiatan diskusi, baik kelompok maupun kelas, siswa mendiskusikan masalah yang dihadapi dalam kegiatan belajar mengajar sebesar $23,52 \%$. Siswa mengemukakan hasil diskusi dan menghubungkannya dengan teori yang ada sebesar 20,58 $\%$. Siswa memberikan penilaian terhadap siswa lain yang telah mengemukakan pendapat sebesar $5,56 \%$. Inti masalah diatas adalah siswa kurang memberdayakan penalaran 
dalam berpikir, sehingga kemampuan berpikir kritis secara riil masih rendah.

Observasi kedua dilakukan sebagai tindak lanjut terhadap hasil observasi awal di kelas XI MIA 6 melalui pemberian soal pada hari Rabu, 22 Oktober 2014. Hasil observasi lanjutan menggunakan indikator kemampuan berpikir kritis menunjukkan bahwa kemampuan interpretasi masih kurang dibuktikan dengan siswa kurang bisa menyatakan arti suatu informasi dari soal, yaitu hanya sebesar 39,70\%. Kemampuan analisis masih kurang dibuktikan hanya sedikit siswa yang menjawab benar dalam menganalisa soal, yaitu hanya $30,88 \%$. Kemampuan evaluasi masih kurang dibuktikan pemberian soal yang bersifat menilai suatu pernyataan, siswa masih belum benar dalam menjawab dengan persentase sebesar $33,82 \%$. Kemampuan penjelasan masih kurang dibuktikan siswa hanya bisa menjelaskan dengan tepat sebesar $36,76 \%$. Kemampuan menyimpulkan masih masih kurang karena siswa kurang bisa menyimpulkan berdasarkan alasan, yaitu hanya sebesar $33,82 \%$. Kemampuan pengaturan diri siswa masih kurang karena soal yang disajikan adalah bersifat mengevaluasi konsep, siswa masih salah dalam menjawab sebesar $35,29 \%$.

Observasi selanjutnya dilakukan menggunakan angket pada hari Senin, 28 Oktober 2014. Hasil observasi lanjutan diketahui bahwa kemampuan berpikir kritis masih rendah, dapat dilihat bahwa aspek interpretasi yaitu 63,23\%, aspek analisis yaitu 59\%, aspek evaluasi yaitu 58,08\%, aspek kesimpulan yaitu $57,90 \%$, aspek penjelasan yaitu $60,11 \%$ dan aspek pengaturan diri yaitu 57,53\%. Selain itu, hasil wawancara dengan siswa menunjukkan bahwa siswa banyak mengeluh karena pembelajaran biologi dianggap sulit, kurangnya keterlibatan siswa dalam penemuan konsep dan sumber belajar serta siswa belum optimal dilibatkan dalam kegiatan pembelajaran seperti kegiatan berdiskusi, menganalisa permasalahan, menyimpulkan kegiatan belajar. Masalah utama yang ada dikelas tersebut adalah siswa kurang memberdayakan berpikir kritis secara riil.

Hasil observasi menunjukkan bahwa kemampuan berpikir kritis siswa kelas XI MIA 6 SMA N 4 Surakarta masih dibawah rata-rata sehingga perlu ditingkatkan. Diidentifikasi bahwa rendahnya kemampuan berpikir kritis diantaranya yaitu proses pembelajaran di sekolah masih menggunakan model pembelajaran kurang mampu mengembangkan potensi siswa yaitu kemampuan berpikir diantaranya kemampuan berpikir kritis.

Kemampuan berpikir kritis menurut Facione (2011) meliputi interpretation (interpretasi), analysis (analisis), inference (kesimpulan), evaluation (evaluasi), explanation (penjelasan), dan self-regulation (pengaturan diri). Kemampuan berpikir kritis merupakan hal penting dan sangat diperlukan peserta didik untuk menghadapi persoalan hidup di masa yang akan datang. Berpikir kritis adalah proses berpikir yang terarah dan jelas yang berpengaruh besar dalam kegiatan mental seorang individu seperti memecahkan masalah, mengambil keputusan, menganalisis asumsi maupun dalam melakukan penelitian ilmiah (Johnson, 2010). Pemecahan suatu masalah memerlukan data yang akurat agar dapat menghasilkan keputusan atau solusi yang logis dan tepat, diperlukan pula kemampuan berpikir kritis yang baik sebagai kemampuan dasar dalam menganalisis data yang ada (Amri dan Ahmadi, 2010).

Salah satu model pembelajaran yang dapat diterapkan, yaitu pembelajaran menggunakan inkuiri, pembelajaran ini dapat mengembangkan seluruh potensi yang terdapat dalam diri siswa secara optimal termasuk kemampuan berpikir kritis siswa. Pembelajaran dengan menggunakan inkuiri dapat meningkatkan intelektual siswa diantaranya adalah berpikir kritis karena siswa diberi kesempatan sendiri untuk menemukan fakta dan konsep tentang fenomena ilmiah yang dapat memunculkan rasa ingin tahu siswa tinggi. Proses inkuiri berarti suatu rangkaian proses belajar mengajar yang melibatkan seluruh kemampuan siswa untuk mencari dan menyelidiki secara sistematis, kritis, logis, analisis, sehingga mereka dapat merumuskan sendiri penemuannya dengan penuh percaya diri. Sasaran pada pembelajaran dengan inkuiri yaitu keterlibatan secara maksimal siswa dalam proses kegiatan belajar (Gulo, 2002).

\section{METODE PENELITIAN}

Penelitian dilaksanakan di kelas X1 MIA 6 SMA Negeri 4 Surakarta. Penelitian ini dilaksanakan pada semester genap, yaitu bulan Maret-April tahun pelajaran 2014/2015. Subjek dalam Penelitian Tindakan Kelas ini diterapkan pada siswa kelas XI MIA 6 SMA N 4 Surakarta semester genap Tahun Pelajaran 2014/2015 yang berjumlah 34 siswa, terdiri dari 15 putra dan 19 putri. Metode penelitian yang digunakan adalah Penelitian Tindakan Kelas (PTK). . Penelitian ini bertujuan untuk memecahkan masalah yang timbul dalam kelas, penelitian dilaksanakan dengan berkolaborasi bersama guru bidang studi. Permasalahan kelas pada penelitian ditangani dengan tindakan berupa aplikasi Model Inkuiri pada materi Sistem Indera. Data yang dikumpulkan dalam penelitian penerapan model Inkuiri berupa data utama mengenai kemampuan berpikir kritis siswa dengan beberapa aspek meliputi interpretasi, analisis, evaluasi, inferensi, penjelasan dan regulasi diri yang diukur dengan menggunakan tes yang disusun peneliti. Data utama kedua berupa angket dan wawancara terkait dengan sikap siswa yang mencerminkan kemampuan berpikir kritisnya.

Teknik yang digunakan untuk mengumpulkan data peningkatan kemampuan berpikir kritis melalui implementasi Model Inkuiri meliputi teknik tes dengan soal multiple choice dan teknik non tes dengan pengamatan atau observasi, wawancara, angket, dan metode dokumentasi. Teknis analisis yang digunakan dalam penelitian adalah deskriptif kualitatif berdasarkan hasil observasi dan refleksi dari tiap-tiap siklus. Prosedur dan langkah-langkah dalam penelitian tindakan kelas ini mengikuti model yang dikembangkan oleh Kemmis dan Mc. Taggart yang berupa model spiral yaitu dalam satu siklus terdiri dari tahap perencanaan, tindakan, observasi dan refleksi (Arikunto, dkk., 2011). 


\section{HASIL DAN PEMBAHASAN}

Tindakan Model Inkuiri dalam riset ini mampu meningkatkan Kemampuan Berpikir Kritis Siswa dari $35,04 \%$ pada pra siklus menjadi $63,97 \%$ pada siklus III. Kemampuan berpikir kritis merupakan kemampuan yang sangat penting dalam kehidupan saat ini. Berpikir kritis dimaksudkan sebagai berpikir yang benar dalam pencarian pengetahuan yang relevan dan reliabel dalam dunia nyata (Sadia, 2008). Berdasarkan hasil penelitian menggunakan tes Kemampuan Berpikir Kritis terdapat peningkatan yang berbeda-beda untuk setiap aspek dari siklus pertama hingga siklus ketiga. Aspek dengan capaian tertinggi dari siklus pertama hingga siklus ketiga adalah aspek penjelasan Selanjutnya aspek dengan capaian tertinggi kedua adalah kesimpulan. Peningkatan hasil kemampuan berpikir kritis dapat disajikan pada Gambar 1.

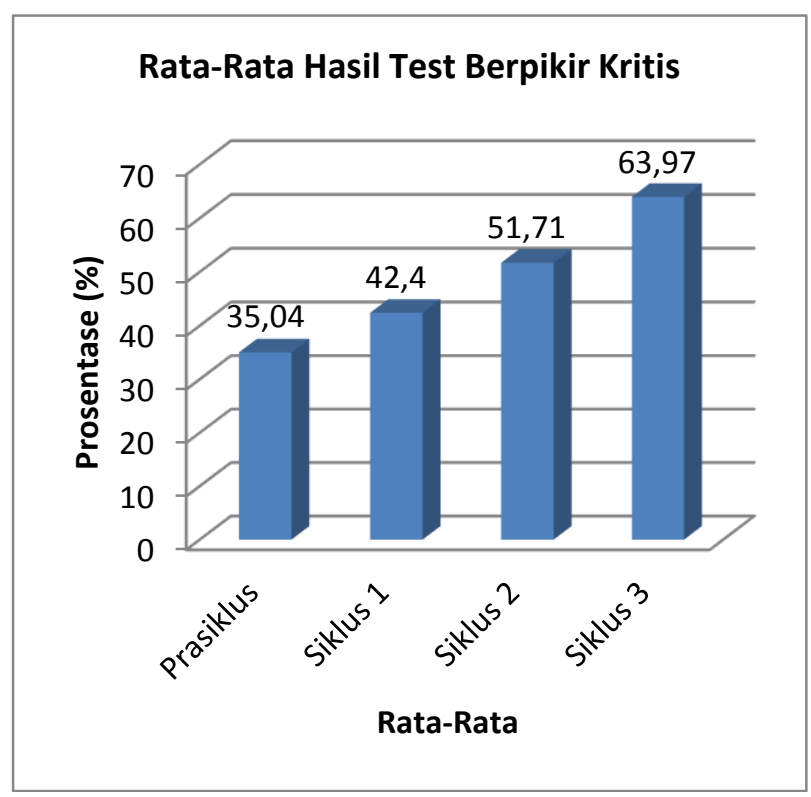

\section{Gambar 1. Peningkatan Hasil Kemampuan} Berpikir Kritis

Peningkatan kemampuan berpikir kritis tersebut juga didukung oleh peningkatan hasil perhitungan angket kemampuan berpikir kritis siswa seperti terjadi peningkatan dari Prasiklus, Siklus I, Siklus II, dan Siklus III yang meliputi: 1) Interpretasi meningkat sebesar 14,95\% dari $63,23 \%$ menjadi $78,18 \%$; 2) Analisis meningkat sebesar $19,49 \%$, dari $59 \%$ menjadi $78,49 \%$; 3) Evaluasi meningkat sebesar 20,78\%, dari 58,08\% menjadi 78,86\%; 4) Kesimpulan meningkat sebesar $20,04 \%$ dari $57,90 \%$ menjadi 77,94\%; 5) Penjelasan meningkat sebesar $18,47 \%$ dari $78,58 \%$ menjadi $60,11 \%$. ; 6) Pengaturan diri meningkat sebesar $19,3 \%$ dari $57,53 \%$ menjadi $76,83 \%$. Peningkatan terbesar dari pra siklus ke siklus III yaitu evaluasi. Selain itu, berdasarkan hasil Lembar Observasi Afektif menunjukkan tampak adanya peningkatan kemampuan afektif di setiap siklusnya, yaitu: 1) Ingin tahu meningkat sebesar $15,81 \%$ dari $41,54 \%$ menjadi $57,35 \%$; 2) Aktif meningkat sebesar $16,54 \%$ dari $38,6 \%$ menjadi $55,14 \%$. Hasil Lembar Observasi psikomotorik juga tampak adanya peningkatan di setiap siklusnya, yaitu: 1)
Mengumpulkan data meningkat sebesar $17,29 \%$ dari $46,68 \%$ menjadi $63,97 \%$; 2) Menganalisis data hasil meningkat sebesar $19,49 \%$ dari $45,95 \%$ menjadi $65,44 \%$; 3) Menarik Kesimpulan sebesar $16,18 \%$ dari $57,34 \%$ menjadi $73,52 \%$. Peningkatan terbesar dari siklus pertama hingga siklus ketiga yaitu menarik kesimpulan.

Model Inkuiri terdiri dari membuat rumusan masalah, merumuskan hipotesis, merancang dan melaksanakan percobaan, analisa data dan membuat kesimpulan. Sintaksintak ini memfasilitasi siswa untuk aktif dalam berpikir tingkat tinggi, khususnya berpikir kritis untuk menemukan konsep pembelajaran. Hal ini sesuai dengan hasil penelitian Hastuti (2014) yang meneliti tentang kemampuan berpikir kritis dengan Model Inkuiri pada kegiatan di kelas. Penggunaan Model Inkuiri sesuai dengan teori belajar penemuan dari Bruner bahwa siswa dianjurkan untuk memperoleh pengalaman dan melakukan eksperimen agar menemukan prinsip-prinsip dalam belajar (Dahar, 2011).

Tahapan pada Model Inkuiri diduga dapat melatih siswa mengembangkan kemampuan berpikir kritis, yaitu aspek interpretasi. Siswa mampu mengelompokkan permasalahan atau fenomena yang diterima, sehingga mempunyai arti dan bermakna jelas. Diskusi yang aktif dapat meningkatkan kemampuan berpikir kritis seperti identifikasi masalah, klasifikasi, kategorisasi dan interpretasi (Jacobsen, 2009). Aspek analisis diperoleh dengan identifikasi permasalahan hingga dapat memperoleh konsep dan deskripsi serta pengajuan opini melalui pengalaman belajar (Facione, 2011). Kemampuan evaluasi dilatihkan pada siswa melalui kegiatan diskusi. Siswa dapat saling menilai atau menanggapi pernyataan temannya, memberikan alternatif jawaban yang lain dan mengevalusi sumber informasi pada saat berdiskusi. Heidare, Poor, \& Poor (2011) menambahkan dengan adanya saran dari hasil presentasi, tahap ini memungkinkan siswa untuk emngembangkan kemampuan berpikir kritis pada aspek evaluasi.

Selain itu, Aspek inference atau menyimpulkan meningkat dengan perlakuan Model Inkuiri. Hal ini sesuai yang dinyatakan oleh Novitasari (2012) bahwa kemampuan berpikir kritis siswa dapat meningkat dengan melibatkan siswa dalam membuktikan suatu pernyataan, memecahkan masalah dan menarik kesimpulan. Aspek pengaturan diri menggunakan Model Inkuiri juga mengalami peningkatan. Peningkatan dan perbaikan dari siklus pertama ke siklus berikutnya membawa perubahan bagi siswa pada aspek self-regulation. Siswa sudah mulai mengecek kembali hasil diskusi mereka tentang percobaan daya sensitivitas bau dan daya sensitivitas lidah pada pembelajaran di siklus kedua. Kemudian, pada siklus ketiga siswa juga sudah mulai mengecek hasil percobaan dengan mengecek apa yang sudah dikerjakan pada LKS indera peraba.

Berdasarkan hasil Lembar Observasi Psikomotorik, terjadi peningkatan aspek kemampuan berpikir kritis pada setiap indikator. Indikator menarik kesimpulan paling tinggi di antara indikator yang lain dari siklus I hingga siklus III. Indikator menarik kesimpulan lebih tinggi dibandingkan mengumpulkan data dan menganalisis data hasil percobaan. Hal ini dikarenakan siswa sudah terbiasa 
untuk merumuskan masalah, mengajukan hipotesis, merancang, dan melakukan percobaan sendiri sehingga mereka dapat mengenali bukti, menjawab hipotesis, dan menarik kesimpulan dengan menggunakan pertimbangan induktif atau deduktif. Hal ini sesuai dengan pernyataan Facione (2011), yaitu siswa dapat mengembangkan aspek berpikir kritis melalui mengenali dan memperoleh unsur yang diperlukan untuk menarik kesimpulan yang masuk akal, memecahkan dugaan dan hipotesis, mempertimbangkan informasi yang relevan dan mengurangi konsekuensi yang ditimbulkan dari data, pernyataan, prinsip, bukti, penilaian, keyakinan, opini, konsep, deskripsi, pernyataan, atau bentuk-bentuk representasi lainnya.

Berdasarkan hasil lembar observasi afektif, terjadi peningkatan pada semua indikator. Indikator ingin tahu lebih tinggi daripada indikator aktif, namun selisihnya tidak banyak. Hal ini dikarenakan Model Inkuiri menimbulkan rasa ingin tahu yang tinggi pada siswa. Siswa belajar dan dilatih bagaimana mereka harus berpikir kritis sehingga kemampuan berpikir kritis siswa akan meningkat karena mereka selalu dihadapkan pada suatu informasi yang harus mereka analisis dan simpulkan (Laurina, 2008).

Jufri (2013) menjelaskan bahwa kemampuan berpikir ilmiah akan berkembang melalui kegiatan inkuiri yang didorong rasa ingin tahu. Keingintahuan merupakan kegiatan berpikir yang harus dirangsang dan dilatih secara teratur. Sejalan dengan apa yang disampaikan oleh Gulo (2002) dalam (Trianto, 2007) yang menyatakan bahwa Model Inkuiri adalah sebuah rangkaian kegiatan belajar yang melibatkan secara maksimal seluruh kemampuan siswa untuk mencari dan menyelidiki secara sistematis, kritis, logis, analitis, sehingga mereka dapat menemukan sendiri penemuannya dengan penuh percaya diri.

Berdasarkan angket yang diberikan setelah siklus selesai juga terjadi peningkatan pada semua aspek. Aspek evaluasi paling tinggi di antara aspek yang lain. Hal ini dikarenakan siswa dapat menilai pendapat yang dibuat, baik secara induktif ataupun deduktif setelah melakukan percobaan yang dirancang secara mandiri (Facione, 2011), sehingga idealnya Model Inkuiri dapat mempengaruhi kemampuan siswa dalam mengevaluasi dari percobaan yang telah dilakukan. Capaian aspek evaluasi pada Lembar Observasi adalah tertinggi dibandingkan aspek yang lainnya, hal ini didukung hasil tes kemampuan berpikir kritis siswa.

Berdasarkan hasil wawancara, siswa dan guru merasa senang dengan kegiatan menggunakan Model Inkuiri dan termotivasi untuk mengikuti setiap aktivitas karena pada setiap siklus terdapat materi dan cara penyampaian yang menarik. Pemahaman konsep pada materi dirasakan lebih mengena oleh siswa, karena selama ini pembelajaran biologi cenderung hafalan dan mencatat. Menggunakan Model Inkuiri dengan melakukan percobaan maka siswa akan lebih memahami materi lebih mendalam. Siswa juga memiliki sumber belajar yang bervariasi, selain itu membantu siswa dalam kegiatan diskusi serta mempresentasikan hasil didepan kelas, sehingga mengembangkan kemampuan berpikir.

\section{KESIMPULAN}

Berdasarkan hasil penelitian dapat disimpulkan bahwa Model Inkuiri dalam pembelajaran biologi dapat diterapkan serta dapat meningkatkan kemampuan berpikir kritis siswa XI MIA 6 SMA N 4 Surakarta Tahun Ajaran 2014/2015, yang meliputi aspek interpretasi, analisis, penjelasan, evaluasi, kesimpulan, dan regulasi diri.

\section{DAFTAR PUSTAKA}

Liliasari. (2011). Peningkatan Kualitas Guru Sains Melalui Pengembangan Keterampilan Berpikir Tingkat Tinggi. Seminar Nasional Pasca Sarjana. Bandung: UPI.

Nursito. (2000). Menggali Kreativitas. Yogyakarta: PT. Mitra Gama Widya

Trilling, B. and Hood, P. (1999). Learning, Technology, and Education Reform in the Kowledge Age. Educational Technology. Mei-Juni, 1-25.

Johnson, E.B. (2010). Contextual Teaching and Learning: Menjadikan Kegiatan Belajar Mengajar Mengasyikkan dan Bermakna. Bandung: Penerbit Kaifa

Facione, P.A. (2011). Critical Thinking: What It Is and Why It Counts. California : Measured Reason and The California Academic Press.

Heidare, A., Poor, S.B., Poor, F.N. (2011). Effect and Evaluation Of Creativity Instructional Methods On Creativity Of Students. Life Science Journal, 8 (4), 402-408

Gulo, W. (2002). Strategi Belajar Mengajar. Jakarta: PT. Grasindo.

Trianto. (2007). Model-Model Pembelajaran Inovatif Berorientasi Konstruktivistik. Jakarta: Prestasi Pustaka Publisher.

Dahar, R.W. (2011). Teori-Teori Belajar dan Pembelajaran. Jakarta : Erlangga

Hastuti, D.W. (2014). Penerapan Metode Inkuiri Untuk Meningkatkan Kemampuan Berpikir Kritis Dan Hasil Belajar Siswa Kelas Va Mata Pelajaran IPS Pokok Bahasan Kegiatan Ekonomi Di SDN Kepatihan 06 Jember. Jember : Universitas Jember Press 